
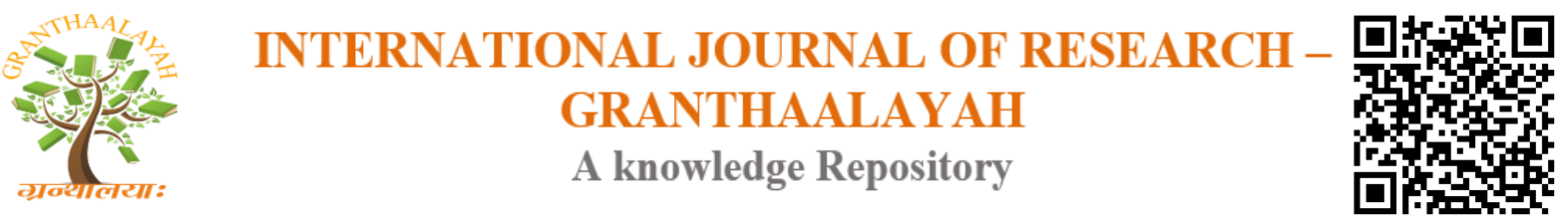

Science

\title{
IMPACT OF THEILERIOSIS ON MILK IN NATURALLY INFECTED COWS AND BUFFALOES AT HYDERABAD
}

\author{
M.I. Memon ${ }^{1}$, N. Memon ${ }^{2}$, A.B. Kachiwal ${ }^{* 1}$, M.R. Memon $^{1}$, S.A. Soomro ${ }^{1}$, Meh- ja- been \\ Memon $^{2}$, Abdullah Sethar ${ }^{3}$ \\ ${ }^{1}$ Sindh Agriculture University, Tandojam, Pakistan \\ ${ }^{2}$ University of Sindh Jamshoro, Pakistan \\ ${ }^{3}$ Livestock and Fisheries Department
}

\begin{abstract}
Study was conducted to investigate the consequences of Theileriosis in naturally infected cattle and buffaloes of urban and peri urban areas of Hyderabad. Chemical analysis of milk of infected cows and buffaloes revealed that protein, ash and lactose were significantly declined $(\mathrm{P}<0.05)$ whereas, fat and total solids were significantly increased $(\mathrm{P}<0.05)$ in Theileria infected cows and buffaloes, but $\mathrm{pH}$ and acidity was unaffected. Financial losses occur in terms of reduced quality and severely decreased quantity of milk and meat. The total financial loss including the mortality and decreased quantity of milk and meat was recorded of Rs. 0.17 million / animal in the current study. Theileriosis is one of the main causes of financial losses for livestock holders.
\end{abstract}

Keywords: Theileria Annulata; Buffaloes and Cows; Decrease Milk Production; Milk Composition.

Cite This Article: M.I. Memon, N. Memon, A.B. Kachiwal, M.R. Memon, S.A. Soomro, Mehja- been Memon, and Abdullah Sethar. (2017). "IMPACT OF THEILERIOSIS ON MILK IN NATURALLY INFECTED COWS AND BUFFALOES AT HYDERABAD." International Journal of Research - Granthaalayah, 5(8), 36-42. 10.29121/granthaalayah.v5.i8.2017.2180.

\section{Introduction}

The livestock plays an important role in rural economy which may be apprehended from the evidence that 35-40 million people are engaged in livestock farming and having 2-3 cows / buffaloes and 5-6 goat/sheep per home which assist them to earn 30 to 40 percent of income (Qudus et al., 2013). The net livestock export earnings is about Rs. 53 billion (Minfal, 2005-06 and Qudus et al., 2013) and contribution of Livestock to agriculture value addition stood at 58.55 percent while it contributes 11.8 percent to the GDP of Pakistan during 2015-16 (GOP, 2016). The population of livestock in Pakistan is about 125 million heads and cattle is the major dairy animal (39.7 million heads) fallowed by buffaloes (34.6 million heads) in Pakistan (GOP, 2014 and Mahmood et al., 2014) 
Pakistan has variety of climatic conditions which are favorable for the ideal growth of vectors. Most of the vectors such as ticks and mosquitoes grow in the hot and humid climates and carry most of the parasitic pathogens in their bodies. The vectors mostly survive on the animal's body and hence transfer different blood born parasitic diseases in the animals and cause losses of billions of rupees due to the decrease in the production of meat, milk, wool, and hide. Hence, the ultimate control strategies are required by our government to control these vectors but in spite of advanced technology and the experts' suggestions no serious pragmatic approach has been launched by our government. Consequently, our dairy production has been vulnerable due to management issues and number of diseases including lack of proper tick and tick borne disease control in Pakistan (Siddiqi et al., 2010). The control measures presently used to shelter animals from theileriosis are costly and all have barriers in effectiveness and sustainability (Hasanpour $e t$ al., 2008).

Theileriosis is one of the ticks born disease and greatly influence on production of milk in livestock due to the sickness, decrease in fertility and high fatality rate and restriction on movement of diseased animals. There are no such published reports for the economic impact of the disease; however global outbreaks have been reported in different parts of the world such as in Australia, Victoria and other parts, where a significant loss in milk production to the dairy industry has been reported because of Theileriosis. Perera et al., (2014) reported that this disease decrease in milk production and impairs the milk composition such as increases the fat percentage and total solids in infected animals milk, where as decrease in milk proteins, ash and no effect on $\mathrm{pH}$ levels of infected animals milk. . Pakistan is the $4^{\text {th }}$ major milk producing country in the world. Milk is produced by buffaloes; cows, goat, sheep and camel. But cows and buffaloes are considered as major dairy animals.

Cows and buffaloes are producing more than $96 \%$ of milk in Pakistan. The rest $4 \%$ of milk is jointly produced by camel, goat and sheep which is mixed with buffalo and cow milk or it may not be sold. Milk is favorite food for the majority of the people of Pakistan and is consumed as boiled, fresh, powdered and in processed form as ghee, butter, yogurt, lassi, cheese, sweets and ice cream and in other confectioneries.

Theileria annulata has devastating impact on small farmers and causing severe economic impact on milk production.

\section{Materials and Methods}

Twenty buffalo farms were selected for study of presence of Theileria species from 2014 - 2015 in urban and peri-urban areas of the Hyderabad, Pakistan. The study was designed to determine the impact of Theileriosis on production and composition of milk in infected cows and buffaloes.

\subsection{Sample Collection}

\section{Study Zone}

Study was conducted in Hyderabad city and its surrounding areas. Hyderabad is a 6th most popular city in Pakistan and second largest city of Sindh province, which is situated $150 \mathrm{~km}$ far from Karachi on the east bank of River Indus, with an elevation of 13 meters (43 ft). Hyderabad 
is connected with Karachi by largest highways known as Indus highway and also with national highway from Hyderabad via Thatta. Economic losses due to mortality, forced culling and reduced milk and meat production were calculated. Direct and Indirect economic losses were also calculated on basis of data collected during study on the designed proforma.

\subsection{Milk Collection and Analysis}

Milk samples were collected in sterilized milk bottles from infected and uninfected cattle and Buffaloes. Strict hygienic measures were followed during milking. Then milk samples were put in the ice box and brought to the Central Veterinary Diagnostic Laboratory Tandojam for analyses of Solids (Total), Ash, Protein, Fat, Lactose, PH and Acidity through automatic milk analyzer.

\section{Results}

The study was performed in order to determine the milk losses in Theileria infected buffaloes and cows in urban and peri urban areas of hyderabad, Sindh, Pakistan during the year $2014-$ 2015.

\subsection{Milk Losses in Theileria Infected Buffaloes and Cows in Urban and Peri Urban Areas of Hyderabad}

Milk yield of healthy buffaloes was $4.732 \mathrm{~kg} /$ day in Peri-urban areas and $5.8 \mathrm{~kg} / \mathrm{day}$ in urban areas of Hyderabad (Fig-1). Milk yield of healthy cows was 5.53 in peri-urban areas of Hyderabad and $5.58 \mathrm{~kg} /$ day in urban areas of Hyderabad. Overall, milk yield of healthy buffaloes was $5.5 \mathrm{~kg} /$ day, whereas, it was $4.5 \mathrm{~kg} /$ day in infected buffaloes (Fig-2 to 3). Milk yield was significantly reduced $(\mathrm{P}<0.01)$ in theileria infected buffaloes as compare to normal buffaloes of urban and peri urban araes of Hyderabad. Overall, milk yield of healthy cows were $6.91 \mathrm{~kg} /$ days, whereas, it was $5.47 \mathrm{~kg} /$ day in infected cows ( Fig-4). Further analysis confirmed that milk yiled per day was significantly reduced $(\mathrm{P}<0.01)$ in theileria infected cows as compare to healthy cows (Fig-4).

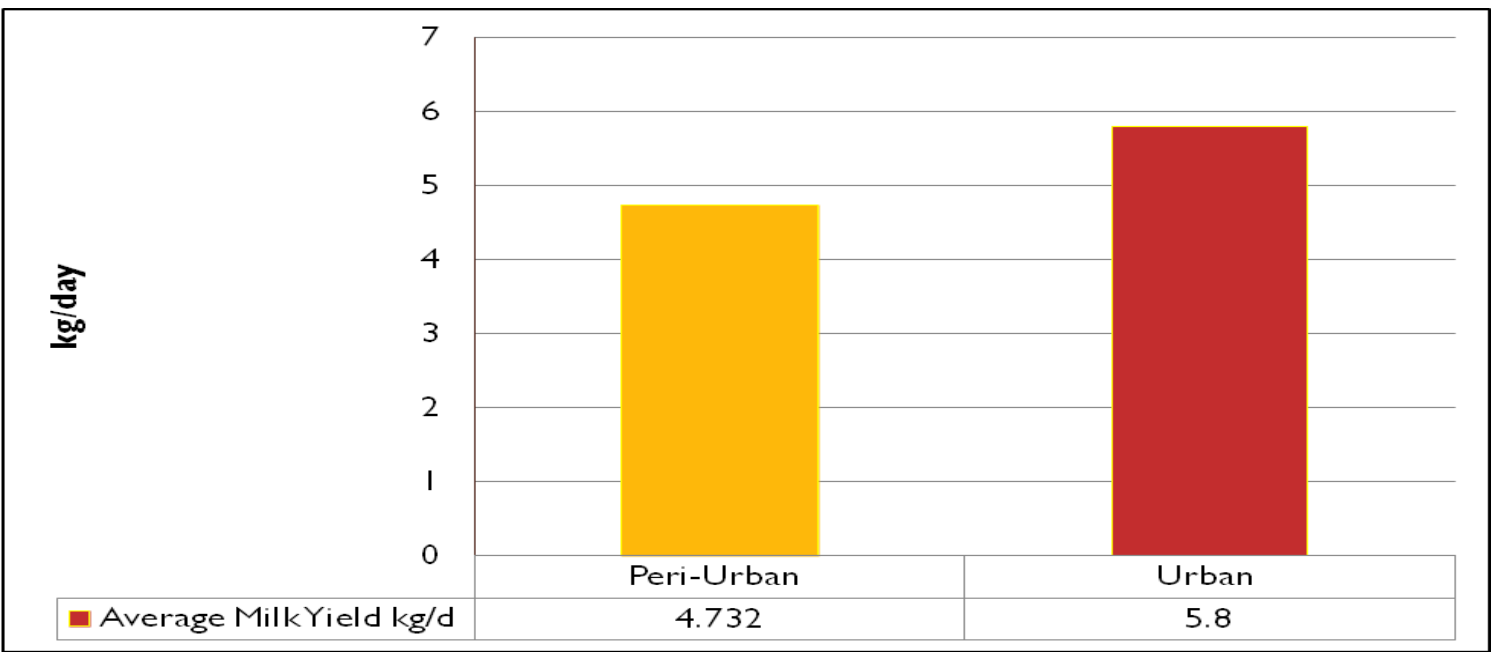

Figure 1: Milk yield of buffaloes of Peri-urban and urban areas of Hyderabad. 


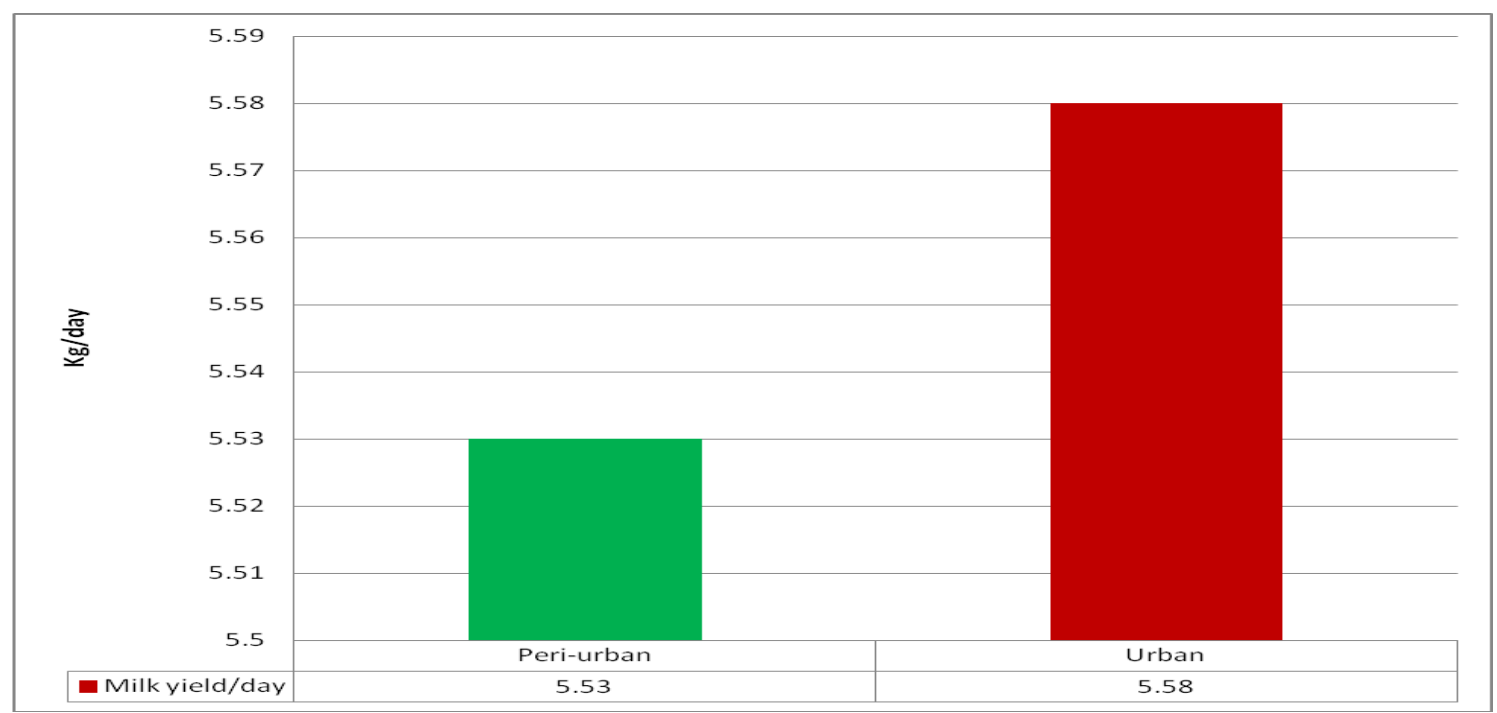

Figure 2: Milk yield of cows of Peri-urban and urban areas of Hyderabad.

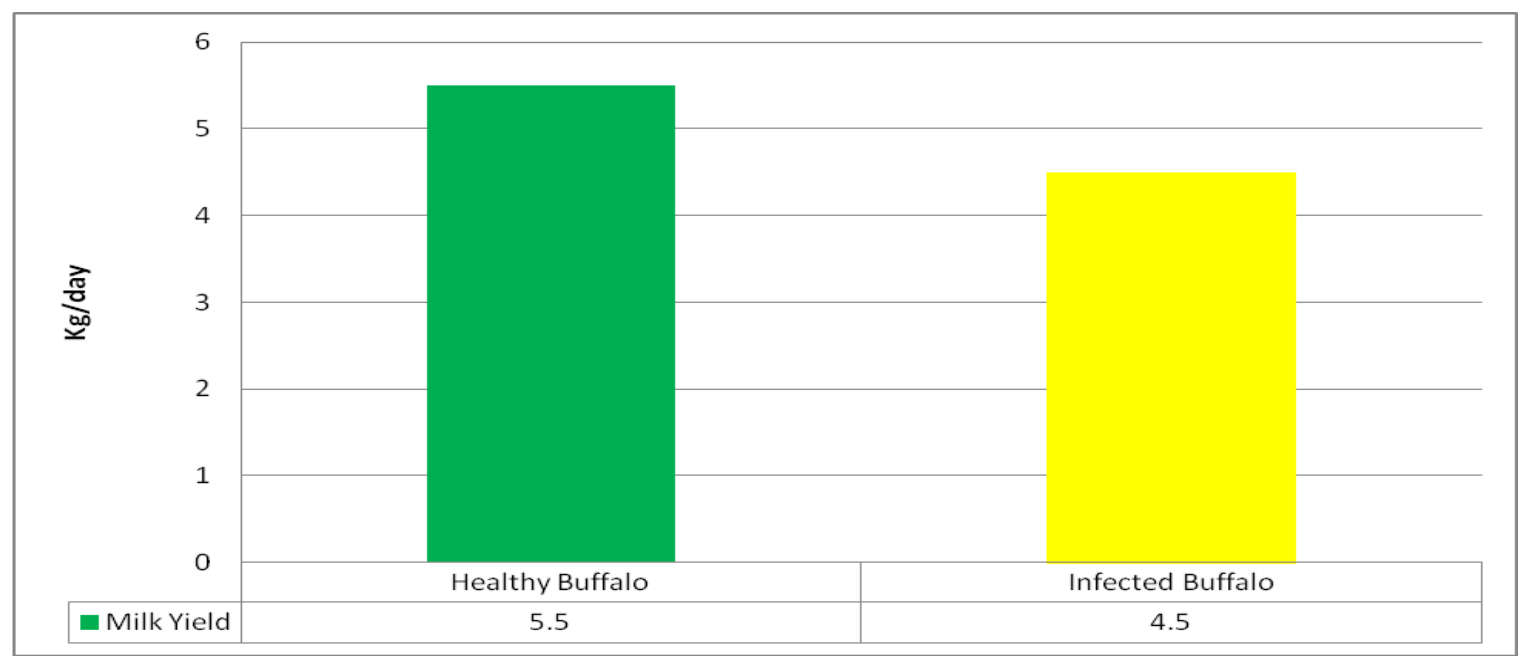

Figure 3: Milk yield of healthy and infected buffaloes of Hyderabad.

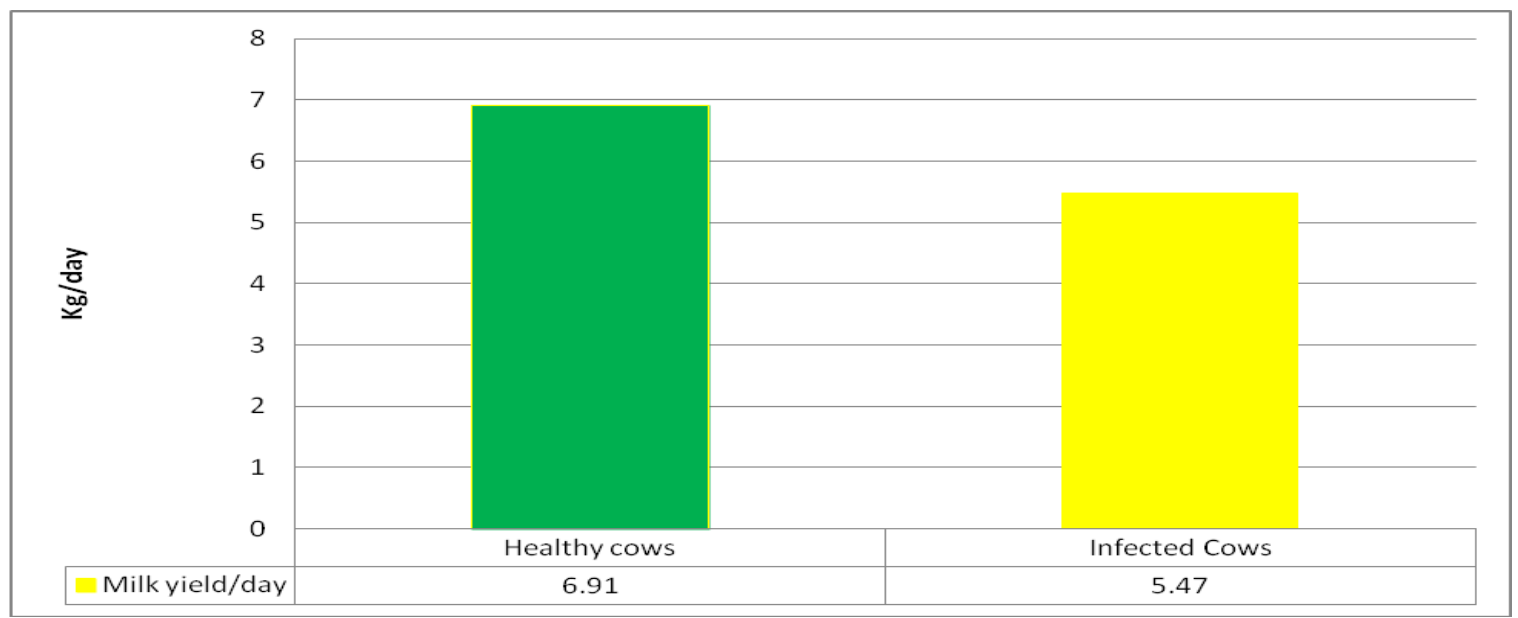

Figure 4: Milk yield of healthy and infected cows of Hyderabad. 


\subsection{Effect of Theileriosis on Milk Composition of Buffaloes of Hyderabad}

Milk composition such as $\mathrm{pH} 6.4$, Acidity $0.17 \%$, Fat $6.77 \%$, protein $3.89 \%$, lactose $4.24 \%$, Ash $0.18 \%$ and solids $15.04 \%$ in healthy buffaloes and theleiria infected buffaloes was $\mathrm{pH} \% 6.9$, Acidity $0.17 \%$, Fat $10.66 \%$, Protein $3.75 \%$, lactose $4 \%$, Ash $0.23 \%$ and solids $20.64 \%$ of urban and peri urban areas of Hyderabad. Further analysis revealed that protein, ash and lactose were significantly declined $(\mathrm{P}<0.05)$ in theileria infected buffaloes, whereas, fat and solids significantly increased $(\mathrm{P}<0.05)$ in thieleria infected buffaloes. But $\mathrm{pH}$ and acidity was unaffected in theileria infected buffaloes (Fig-5).

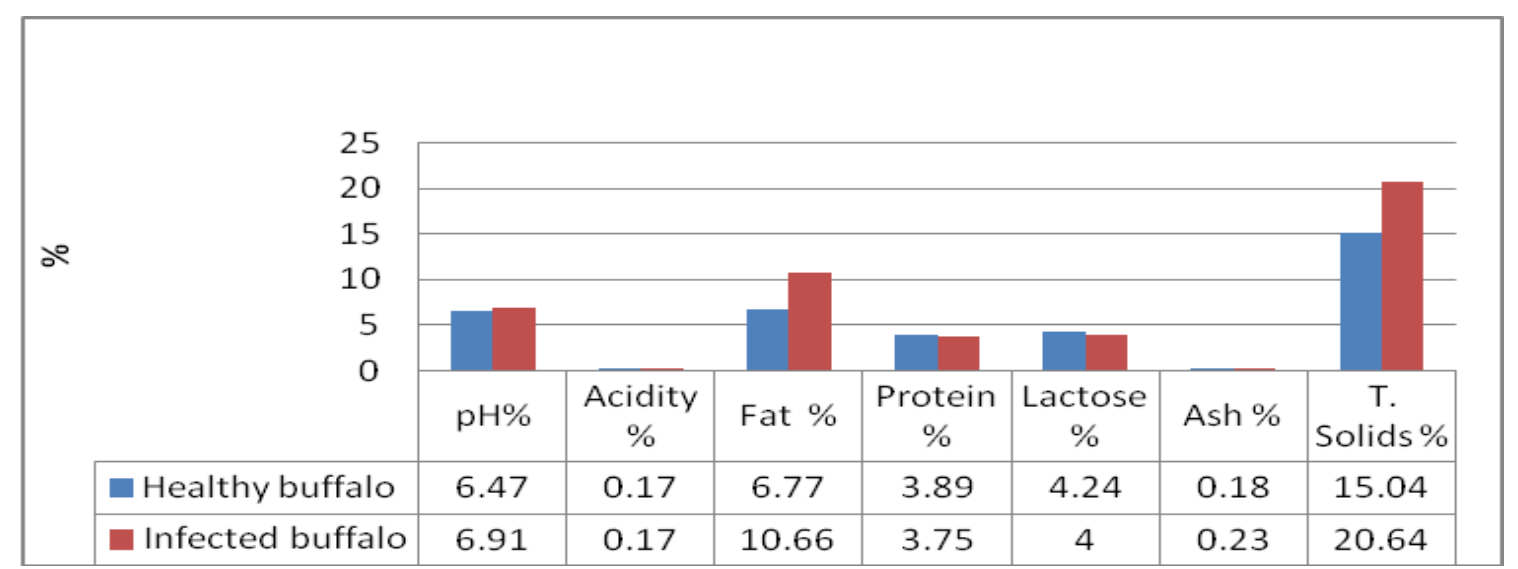

Figure 5: Composition of milk of healthy and infected buffaloes of Hyderabad.

\subsection{Effect of Theileriosis on Milk Composition of Cows of Hyderabad}

Milk composition such as $\mathrm{pH} 6.69 \%$, Acidity $0.17 \%$, Fat 5.97\%, protein 3.58\%, lactose 5.2\%, Ash $0.23 \%$ and solids $15.42 \%$ in healthy cows and milk composition of theleiria infected cows was $\mathrm{pH} \% 6.69 \%$, Acidity $0.17 \%$, Fat $6.5 \%$, Protein $3.46 \%$, lactose $4.5 \%$, Ash $0.18 \%$ and solids $17.6 \%$ in urban and peri urban areas of Hyderabad. Further analysis revealed that protein, ash and lactose were significantly declined $(\mathrm{P}<0.05)$ in theileria infected cows and buffaloes, whereas, fat and total solids were significantly increased $(\mathrm{P}<0.05)$ in thieleria infected cows and buffaloes. But $\mathrm{pH}$ and acidity was unaffected in theileria infected cows (Fig- 6).

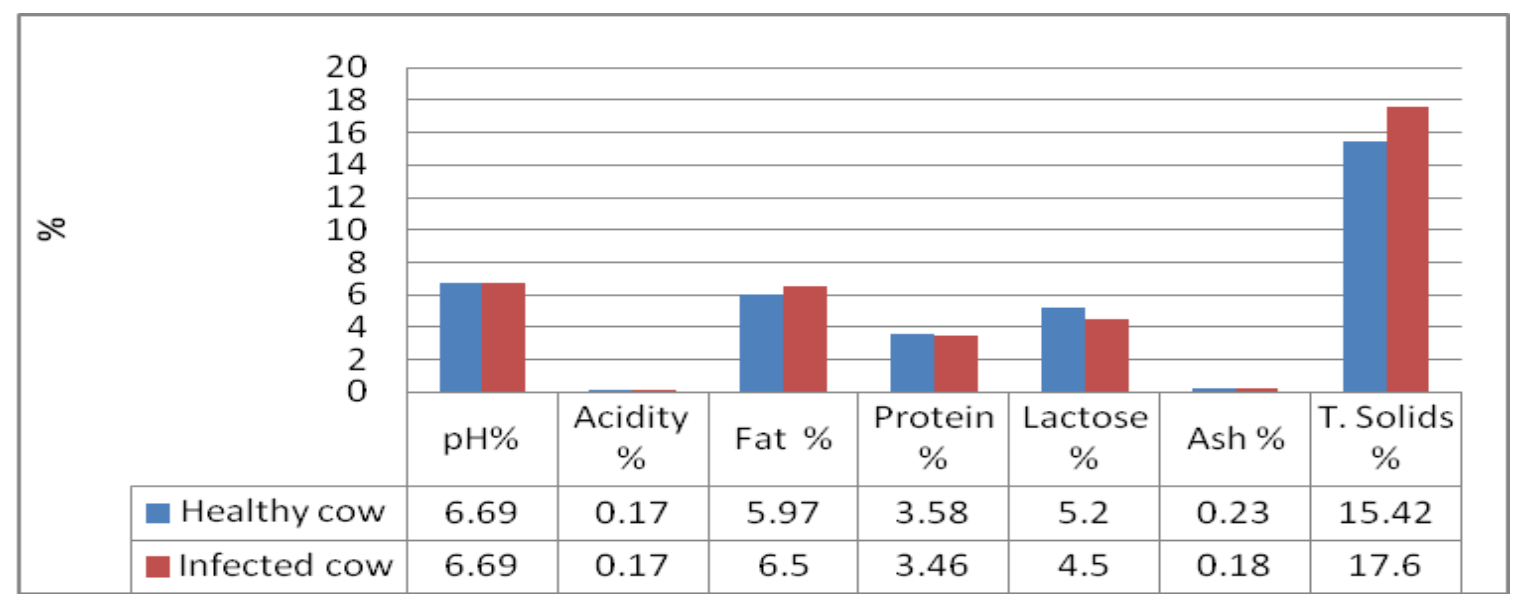

Figure 6: Composition of milk of healthy and infected cows of Hyderabad. 


\section{Discussion}

In this study, milk yield and milk composition was significantly affected in theileria infected buffaloes and cows. Perera et al., (2014) reported significantly less milk production (624 1; $\mathrm{P}=$ $0.004)$, milk protein $(26.0 \mathrm{~kg} ; \mathrm{P}<0.001)$ and milk fat $(42.9 \mathrm{~kg} ; \mathrm{P}<0.001)$ in Theileria infected cows as compared with normal cows. Production losses due to Theileria in bovines have also been reported in Kenya by Latif et al.,(1995) and Muraguri et al., (1998) and in Tanzania by Homewood et al., (2006), Kivaria et al.,(2006) and Kivaria et al.,(2007). In addition, mortality rates associated with theileriosis caused by $T$. annulata and production losses have been reported from Turkey by Inci et al., (2006). In Australia in (1997), ticks and tick-borne diseases caused economic losses to cost USD 7.8 per head in cattle is significantly higher reported by Brown et al., (1997). In adding up, the economic losses projected by Kivaria et al., (2007) were computed by totaling the cost of treatment, costs of milk loss, weight loss and immunization Kivaria et al., (2007), but in my study economic losses were calculated by adding cost of loss milk and meat and death of animal.

\section{References}

[1] Brown, C., G. C. Stagg, D. A.Purnell, R. E. Kanhai, and G. K. Paynie ( 1997). T anulata: cross reactions between a cell culture schizont antigen and antigens East African Theileria species in the indirect fluorescent antibody test. Exp. Parasitol. 35:374-38

[2] GOP (2014) Economic Survey of Pakistan 2013-14. Economic Advisor's Wing, Finance Division, Government of Pakistan Islamabad.

[3] GOP (2016). Economic Survey of Pakistan 2015-16. Economic Advisor's Wing, Finance Division, Government of Pakistan Islamabad.

[4] Hasanpour A, GA Moghaddam and A Nematollahi,( 2008). Biochemical, hematological and Electrocardiographic changes in buffaloes naturally infected with Theileria annulata. Korean $\mathbf{J}$ Parasitol, 46: 223-227

[5] Homewood K, Trench P, Randall S, Lynen G, Bishop B (2006). Livestock health and socioeconomic impacts of a veterinary intervention in Maasailand: Infection-and-treatement vaccine against East Coast fever. Agricult Sys, 89:248-271.

[6] Inci A, Ica A, Yildirim A, Vatansever Z, Cakmak A, Albasan H, Cam Y, Atasever A, Sariozkan S, Duzlu O, (2006). Economical impact of tropical theileriosis in the Cappadocia region of Turkey. Parasitol Res, 101:S171-S174.

[7] Kivaria FM (2006). Estimated direct economic costs associated with tick-borne diseases on cattle in Tanzania. Trop Anim Health Prod, 38:291-299.

[8] Kivaria FM, Ruheta MR, Mkonyi PA, Malamsha PC (2007). Epidemiological aspects and economic impact of bovine theileriosis (East Coast fever) and its control: A preliminary assessment with special refernce to Kibaha district, Tanzania. Vet J, 173:384-390.

[9] Latif AA, Rowlands GJ, Punyua DK, Hassan SM, Capstick PB, (1995). An epidemiological study of tick-borne diseases and their effects on productivity of zebu cattle under traditional management on Rusinga Island, western Kenya. Prev Vet Med, 22:169-181

[10] Mahmood, H. Z., I. Hussain, S. Iftikhar, M. Khan and F. R. Nisa,( 2014). Role of Livestock in Food Security: An Ascertainment from Punjab Pakistan. International Journal of Academic Research in Business and Social Sciences, 4, 458-470

[11] MinFAL, (2006) Ministry of Food, Agriculture and Livestock. Economic Survey (2015-2016)

[12] Muraguri GR, Mbogo SK, McHardy N, Kariuki DP ( 1998) Cost analysis of immunisation against East Coast fever on smallholder dairy farms in Kenya. Prev Vet Med, 34:307-316. 
[13] Siddiqi AZ, MB Uddin, MB Hasan, MF Hossain, MM Rahman, BC Das, MS Sarker and MA Hossain, (2010). Coproscopic and haematological approaches to determine the 116 prevalence of helminthiasis and protozoan diseases of Red Chittagong Cattle (RCC) breed in Bangladesh. Pak Vet J, 30: 1-6.

[14] Perera PK, Gasser RB1, Firestone SM, Anderson GA, Malmo J, Davis G, Beggs DS, Jabbar A (2014). Oriental theileriosis in dairy cows causes a significant milk production loss. Parasit Vectors. 2014 Feb 19; 7:73. doi: 10.1186/1756-3305-7-73.

[15] Qudus, M., N. Ahmad, K. Javed, M. Abdullah, M. Jabbar, M. Omer, Z. Iqbal and I. Ahmad, (2013). Effect of recombinant bovine somatotropin on milk production and composition of lactating Beetal goats. The Journal of Animal and Plant Sciences, 23, 26-30.

*Corresponding author.

E-mail address: kachiwal2003@gmail.com 